\title{
琵琶湖周辺に分布する黒色土中の黒色植物片について 一黒色土中の微粒炭研究の新たな取り組み一
}

\author{
井上淳*吉川 周 作*
}

\begin{abstract}
琵琶湖西岸に分布する黒色土から採取した黒色植物片について各種分析を行い，微粒炭 (高温 被熱によって生成した微細な炭) であるかを検討した。 その結果, 黒色植物片は被熱生成した炭 之同様に, 反射顕微鏡下で白く輝く特徵, 高い反射率, 低い $\mathrm{H} / \mathrm{C}$ 比 (水素・炭素比) が認められ, 黒色植物片は植物の被熱によって生成された微粒炭であると考えられた. また，反射率や $\mathrm{H} / \mathrm{C}$ 比 を基に推定された炭化温度から, 微粒炭は林野火災や火入れなどの植物燃焼によって生成したと 考えられた. 土壤中の微粒炭は, AT 火山ガラスの多産層位より上位から含まれ, $\mathrm{K}-\mathrm{Ah}$ 火山ガラ スの多産層位付近で最む多く含まれていた。 こうした微粒炭量の傾向は琵琶湖湖底堆積物であ認 められ, 琵琶湖湖底堆積物に含まれる微粒炭の発生源の 1 つとして, 琵琶湖周辺の黒色土分布域 が考えられる.
\end{abstract}

キーワード : 黒色土, 琵琶湖周辺, 微粒炭, 高温炭化, 琵琶湖湖底堆積物

\section{I. は じめに}

日本では，東日本や九州を中心に，黒色の土壌が厚く 広域に分布している。これらは黒色土，黒ボク土などと 呼ばれ，第四紀末期に生成したと考えられている. また， 黒色土の生成には, 植生, 火山灰, 地形などの特定の条件 が必要と考えられている(例えば，細野・佐瀬，1997). こうした黒色土生成条件の 1 つとて, 微粒炭 (高温被 熱によって生成した微細な炭)をあげる研究者あいる (阪口，1987；山野井，1996). また，これまでの研究に よって, 黒色土中には微粒炭と考えられる黒色植物片が 含まれることも報告されている (山野井, 1996 ; 鳥居ほ か, 1998 ; 小椋ほか, 2002). 山野井 (1996) は, 東北地方 に分布する黒色土から黒色植物片を見出し, 人為的な植 物燃焼 (野焼き, 山焼き)によって発生した微粒炭であ ると解釈した. そして, 微粒炭が可溶腐植を吸着し, 黒 色土が生成したと考えた。このように黒色土中に含まれ る黒色植物片は，植物の燃焼によって生成された微粒炭 であるとされ，黒色土の生成において重要な役割を果た した，としばしば考えられている。しかし，これまでの 多くの研究は, 黒色植物片の外観特徴が微粒炭に類似す
ることから，黒色植物片を微粒炭と解釈している．この ため, 黒色植物片が微粒炭である確証はなく, その成因 は不明瞭である.

本研究では，黒色土中の黒色植物片の成因，さらに第 四紀の植物燃焼史を考える上での新たな研究法を提示す る. 具体的には, 琵琶湖西岸に分布する黒色土中の黒色 植物片に焦点を当て, 元素組成や光学的性質を調べるこ とにより, 高温炭化したあのかどうか, すなわち微粒炭 か否かを精查した. さらに, 黒色植物片の粒径から, そ の生成場所を検討した. また，黑色土中の黑色植物片含 有量の垂直変動を明らかにし, 井上ほか (2001) の琵琶 湖湖底堆積物 (高島沖ボーリングコア) に含まれる微粒 炭量の変化と比較した. なお, 本研究では黒色土に含ま れる黒色植物片のうち, 微粒炭に類似する外観特徵 (完 全に黒色で植物組織に沿って光沢が見られる特徵)か認 められるあのを研究対象とした. 本研究では, 試料採取 地周辺に分布する土壌について鳥居ほ力（1998）に従い， 「黒色土」(土じょう部，1976）という名称を用いる.

\section{II. 分 析 試 料}

試料採取は, 滋賀県高島市 (旧新旭町) で行った（図

2004 年 12 月 2 日受付. 2005 年 7 月 23 日受理.

* 大阪市立大学大学院理学研究科 =558-8585 大阪市住吉区杉本 3-3-138. 


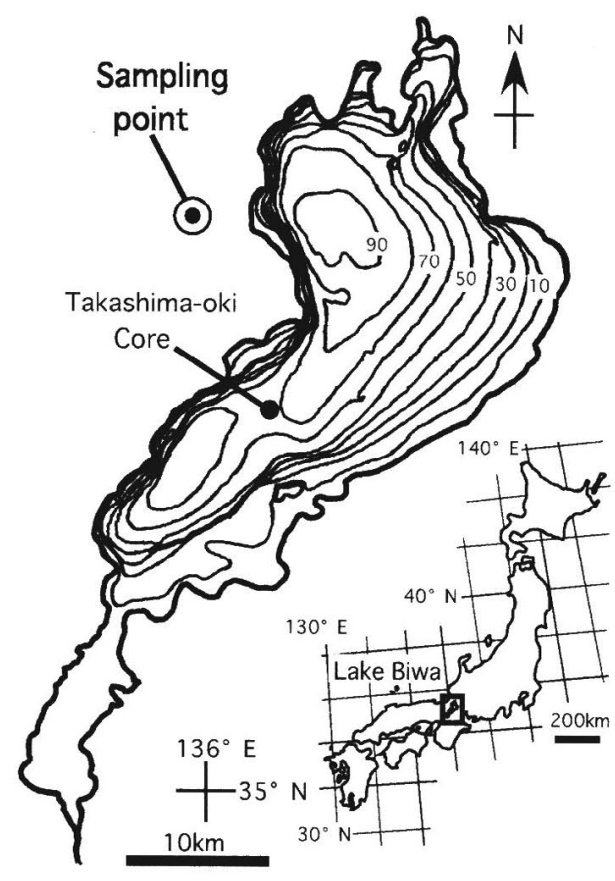

図 1 琵琶湖位置図上黑色土試料採取位置図
1). 約 $1 \mathrm{~m}$ 四方，深さ $1 \mathrm{~m}$ の穴をスコップを用いて掘削 し，その断面において地表から深度 $90 \mathrm{~cm}$ まで，厚さ約 $2 \mathrm{~cm}$ で連続的に 41 試料を採取し，このうち 15 試料を 本研究の分析に用いた. また，これとは別に深度 25〜30 $\mathrm{cm}, 45 \sim 50 \mathrm{~cm}$ で, それぞれ反射率測定，化学組成分析 用試料を採取した.

試料採取した土堙は，地表から深度 $52 \mathrm{~cm}$ までが黒色 の土層 (土壌学分野での A 層), 深度 $58 \mathrm{~cm}$ 以下は褐色 の土層 (B 層), 深度 52〜 $58 \mathrm{~cm}$ は両者の漸移層となって いる(図 2).なお，同地域の黒色十の分布域は200３00 ha 程度で, 黒色十分布地域の地質は段丘堆積物であり, また周辺植生はアカマツ疎林である(日本の地質「近畿 地方」編集委員会，1987；鳥居ほか，1998）。現地で概観 した限りでは，大規模な土地改变が行われた様子はな

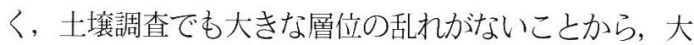
きな土壤の攪乱はなかったと思われる. 同地域の黒色土 については, 烏居ほか（1998）により，鉱物組成，植物珪 酸体，花粉などの分析が行われた。この研究によると， 同地域に分布する黒色土は堆積物としての要素か溞く, 下部から上部に累積的に発達したと考えられている.
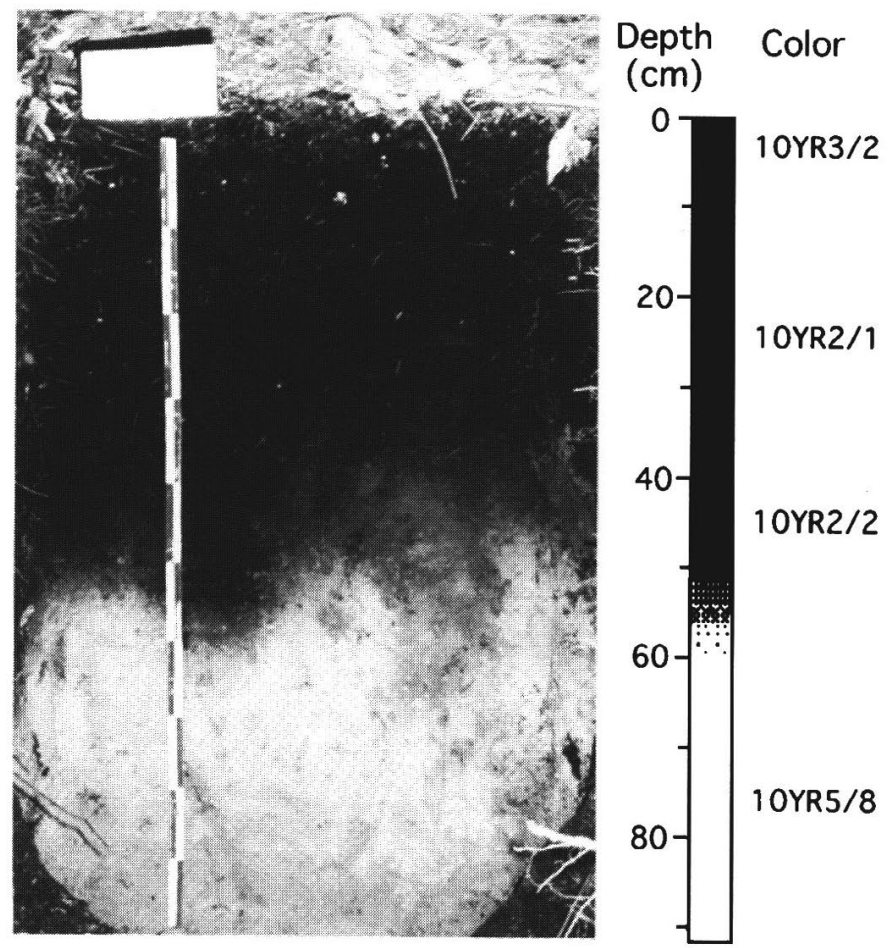

闵 2 黒色土断面写真と模式柱:状网 


\section{III. 分 析方 法}

\section{1. 含有量分析}

黒色植物片含有量の測定にあたり, 井上ほか (2005)の 微粒炭分析方法に準じて行った. 一般に, 微粒炭分析で は約 $100 \mu \mathrm{m}$ 以下の microscopic charcoal 対象とし たものと, 約 $100 \mu \mathrm{m}$ 以上の macroscopic charcoal を 対象としたものに分けて行われる(例えば, MacDonald et al., 1991; 井上ほか, 2005). 本研究でも, おもに約 $100 \mu \mathrm{m}$ 以下のものを測定するために用いられる花粉ス ライド法 (pollen slide method : Swain, 1973 ; 井上ほ か, 2001，2005など）と, 約 $100 \mu \mathrm{m}$ 以上のものを測定す る篩い分け法 (sieving method : Whitlock and Larsen, 2001 ; 井上ほか，2005なよ゙）の2つの分析法を併用し t.

花粉スライド法は，厚さ約 $2 \mathrm{~cm}$ で採取した試料のう ち0 12 試料を以下の手順で分析した. 乾燥試料を約 0.2 $\mathrm{g}$ 秤量した後, 滤過水 (水道水を $1 \mu \mathrm{m}$ フィル夕ーに通 したもの)を加えて十分に眯濁させた. そして，これに 計数マーカーとして一定濃度 (約 20 万個/ $\mathrm{ml}$ ) のマイ クロスフェアー（直径 $25 \mu \mathrm{m}$ のプラスチック球）懸濁液 (Ogdens III, 1986)1 ml 在添加した. 堆積物の泥化, 珪 酸鉱物の除去, 有機物の除去のため, 各試料に $\mathrm{KOH}$ 処 理, HF 処理およびアセトリシス処理を行った。また, $\mathrm{KOH}$ 処理後, $250 \mu \mathrm{m}$ の篩いを通し, 大型の異物・植物 遺体を除去した. 以上の処理後に，グリセリンゼリーを 封入剂としてプレパラートを作成し, 対物レンズ 20 倍, 接眼レンズ 10 倍の金属顕微鏡を用いて，透過光および 落射光下で検鏡を行った，含有量測定にあたっては，透
過光観察時に完全に黒色かつ鋭角的で，落射光観察時に 植物組織が見られ，光反射か認められる粒子を測定対象 とした。 なお，測定は $1,000 \mu \mathrm{m}^{2}$ 以上のものについて面 積測定を行い，マイクロスフェアーの出現合計が 200 個 以上になるまで測定を行った. その後, 乾燥試料 $1 \mathrm{~g}$ 当 たりの総面積を算出した. 面積測定には，光学顕微鏡の 画像を CCD カメラでパーソナルコンピュー夕に取り込 み, アプリケーションソフト NIH Image (National Institute of Health, USA)によって画像処理を行う方法 （高原，1995）を用いた。

篩い分け法は, 厚さ約 $2 \mathrm{~cm}$ で採取した 15 試料を以下 の手順で行った. 乾燥試料を約 $0.2 \mathrm{~g}$ 科量後, 分散と有 機物の分解・漂白のため, 約 $6 \%$ の過酸化水素水を加え て, 約 $50^{\circ} \mathrm{C}$ で約 48 時間の放置を 2 度繰り返した. その 後, $125 \mu \mathrm{m}$ の篩に通し, $125 \mu \mathrm{m}$ 以上の残查についてグ リッドのついたシャーレ上にひろげ，乾燥後，実体顕微 鏡を用いて全面検鏡した，測定は，完全に黒色で植物組 織に沿って光沢の見られる粒子 (図 3)について行った. 測定にあたっては，花粉スライド法と同様に顕微鏡の画 像を CCD カメラでパーソナルコンピュータに取り込 み, NIH Image を用いてそれぞれの植物片の面積を測 定した. そして, 乾燥試料 $1 \mathrm{~g}$ あたりの植物片の総面積 を算出した，また，長軸長 $500 \mu \mathrm{m}$ を超えるむのについ ては, 別途個数屯測定した.

\section{2. 反射率測 定}

黒色土中の黒色植物片について, 反射率測定 (油浸法) を行った. 反射率測定は，深度 $25 \sim 30 \mathrm{~cm}$ に含まれる黒 色植物片について，千々和ほか(1998)の方法に準じて, 以下の手順で行った. $125 \mu \mathrm{m}$ 以上の黒色植物片をポリ
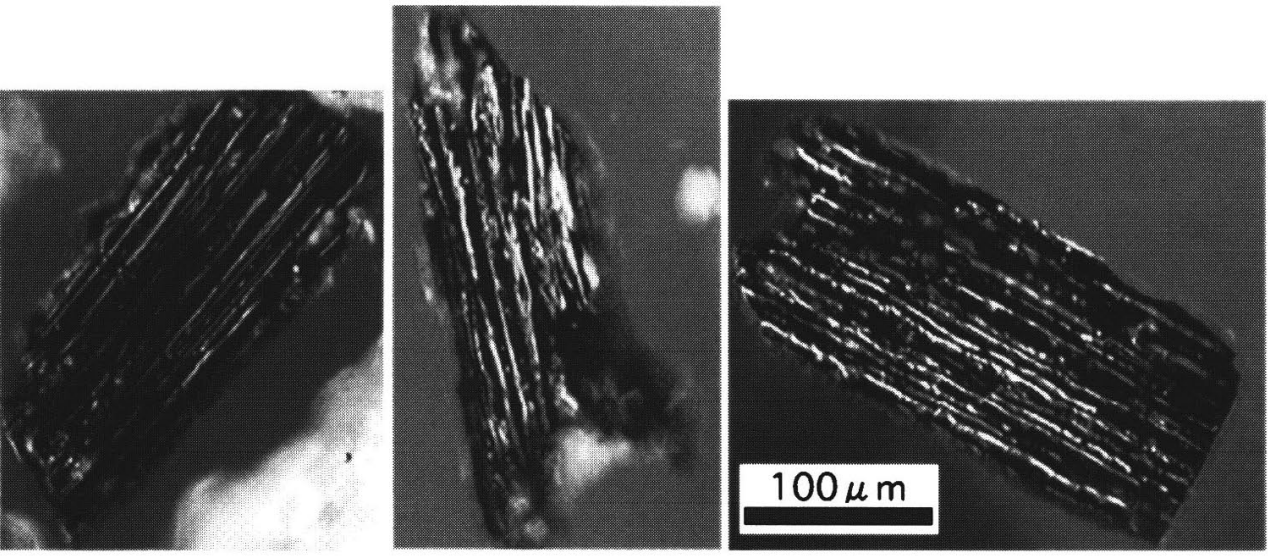

図 3 研究対象とした黒色土中に含まれる黒色植物片の写真 
エステル樹脂に埋め込み，ブリケットを作成した，そし て, 樹脂が固化した後に, 自動研磨機を用いて十分に研 磨した. 作成したブリケット中の黒色植物片について,

顕微測光装置 Leitz MPV combi および光電子倍増管を 内蔵した MPV compact 測定ヘッド (Leica 社製) を用 いて, 黒色植物片の反射率測定を行った. なお, 反射率 測定は植物片 50 点について行った.

\section{3. 元素分 析 $(\mathrm{H} / \mathrm{C}$ 比)}

元素分析は, 深度 $45 \sim 50 \mathrm{~cm}$ から採取した土㙥試料中 の $250 \mu \mathrm{m}$ 以上の黒色植物片について行った. Sawada et al. (2000) に準じて, 以下の前処理を行った. まず, 純 水を用いて洗浄後, 0.5 規定の $\mathrm{NaOH}$ 溶液を用いて, 超 音波洗浄および加熱洗浄した. その後, 1 規定の塩酸溶 液を用いて, 超音波洗浄および加熱洗浄した. 洗浄は, 溶液が無色透明になるまで繰り返し行った. その後, 純 水を用いて洗浄した. 次に, $110^{\circ} \mathrm{C}$ で乾燥させ, メノウ乳 鉢で粉末にし, さらに試料を数時間乾燥させた後, 旧力 ルエロエルバ社製元素分析器 FISONS E.A. 1108 を用い て水素・炭素含有率の分析を行った.

\section{IV. 分 析 結 果}

\section{1. 含有量分析}

花粉スライド法による乾燥試料 $1 \mathrm{~g}$ あたりの黒色植物 片含有量 (面積量) を図 4 左に示す. 深度 $62 \mathrm{~cm}$ 以深で は, 約 $13 \mathrm{~mm}^{2}$ 以下とほとんど含まれない. 特に深度 74 〜 $76 \mathrm{~cm}$ では, 植物片は検出されなかった. 深度 $54 \mathrm{~cm}$ から $20 \mathrm{~cm}$ に加けては, 深度 $32 \sim 34 \mathrm{~cm}$ で一時的に減少 するあのの, 大局的には約 $357 \mathrm{~mm}^{2}$ から約 $1,781 \mathrm{~mm}^{2}$ へと著しく増加する. それより上位では, 減少傾向にあ り, 深度 $4 \sim 6 \mathrm{~cm}$ では約 $675 \mathrm{~mm}^{2}$ となる.

篩い分け法 (図 4 右) による, 乾燥試料 $1 \mathrm{~g}$ あたりの $250 \mu \mathrm{m}$ 以上の黒色植物片含有量 (面積量) は, 深度 54 $\mathrm{cm}$ 以深では約 $0.2 \mathrm{~mm}^{2}$ 以下と非常に少ない. 深度 54 $\mathrm{cm}$ 加ら $40 \mathrm{~cm}$ まで急激に増加する. 深度 $40 \mathrm{~cm}$ から梁 度 $20 \mathrm{~cm}$ では, 約 19 25 $\mathrm{mm}^{2}$ と高い值をとり, 増加傾 向にある. 深度 $20 \mathrm{~cm}$ 以浅では減少傾向にあり, $14 \mathrm{~cm}$ 以浅では約 $5 \mathrm{~mm}^{2}$ 以下となる. また, 深度 $48 \sim 14 \mathrm{~cm}$ の 試料中から, 長軸長 $500 \mu \mathrm{m}$ 以上の大きい黑色植物片が 検出された.

\section{2. 反射率 測 定}

深度 25〜 30 cm に含まれる植物片の反射率ヒストグ ラム, 最大値, 最小值, 平均值を図 5 に示す.

\section{3. 元素分 析 (H/C 比)}

深度 45 50 cm 中の黑色植物片の炭素含有率は 55.7

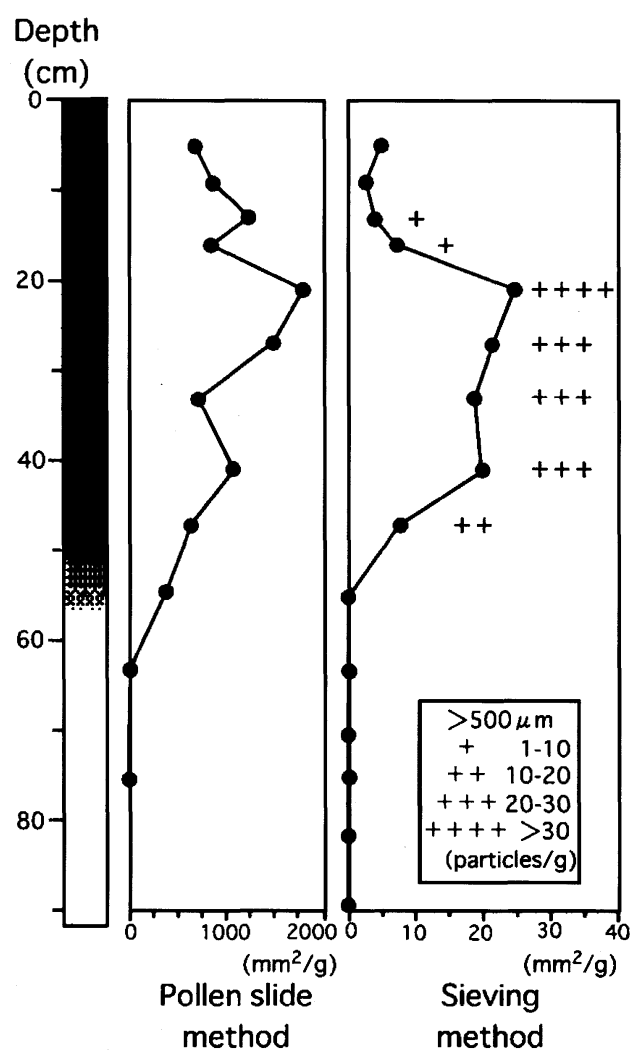

図 4 黑色土中の黑色植物片含有量 花粉スライド法と篩い分け法による黒色植物片含有量. 右端に乾燥試料 $1 \mathrm{~g}$ 中に含まれる $500 \mu \mathrm{m}$ 以上の植物片 の個数を示す.

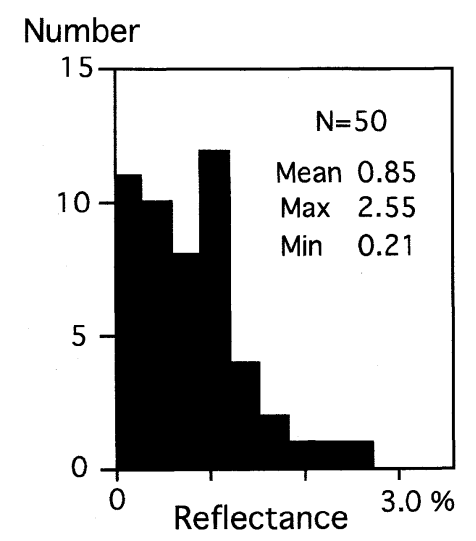

図 5 黒色土深度 $25 \sim 30 \mathrm{~cm}$ の黒色植物片反射率の ヒストグラム 
(wt\%)で，水素含有率は2.2(wt\%)であった．これら の值加ら算出した $\mathrm{H} / \mathrm{C}$ 比 (水素・炭素比) は 0.471 であ る.なお，同分析結果は Inoue and Yoshikawa (2003) の $\mathrm{H} / \mathrm{C}$ 比と反射率の関係の議論に用いられている.

\section{V. 考 察}

\section{1. 黒色植物片の成因}

黒色植物片は，下位の褐色の土層では少なく，上位の 黒色の土層中に多く含まれ，深度 $20 \sim 22 \mathrm{~cm}$ で最屯多く なり, 最大で $1,781 \mathrm{~mm}^{2} / \mathrm{g}$ (花粉スライド法), $25 \mathrm{~mm}^{2} /$ $\mathrm{g}$ (篩い分け法) と多量に含まれていた(図4)。これらの 黒色植物片を反射顕微鏡下で観察すると，森林火災・火 入れ跡加ら採取した炭と同様に, 細胞壁が白く輝いてい る (図 6)。 また，深度 $25 \sim 30 \mathrm{~cm}$ に含ま机る黒色植物片 の反射率は, 最大で $2.55 \%$ と高い(図 5). Jones et al. （1991）やScott（2000）によると, 植物片が高温炭化した 場合には, 細胞壁が白色に輝き, 高い反射率を示すこと か報告されている. また, 深度 $45 \sim 50 \mathrm{~cm}$ から採取され た黒色植物片の $\mathrm{H} / \mathrm{C}$ 比は 0.471 である. Sawada et al. （2000）は，さまざまな温度で炭を生成した結果，加熱に 伴って H/C 比が減少するこ上を明らかにし，およそ $300^{\circ} \mathrm{C}$ 以上で高温炭化した場合に, $\mathrm{H} / \mathrm{C}$ 比は約 1 以下と なることを示している．琵琶湖西岸に分布する黒色土に 含まれる黒色植物片は，火災跡加ら採取した炭や実験的 に高温炭化した炭と同様の性質・特徴をむつことから, これらは高温炭化によって生成された微細な炭（微粒 炭) と考えられる.

Jones et al. (1991)は, 反射率は炭化温度が高くなる につ譄加することを報告し，両者の関係について近似
曲線を描いている．この近似曲線にあてはめると，深度 25 30 cm の黒色土の微粒炭の炭化温度は, 約 250 $500^{\circ} \mathrm{C}$ 程度であったと推測される. また, Sawada et al. (2000) は, 水素・炭素比之炭化温度の間に $\log \mathrm{T}\left({ }^{\circ} \mathrm{C}\right)=$ $2.50-0.530 \log (\mathrm{H} / \mathrm{C})$ (ただし， $\mathrm{T}$ : 炭化温度, H/C : 水 素・炭素比) の関係があることを示した．これに基づく 上, 深度 $45 \sim 50 \mathrm{~cm}$ に含まれた黒色土中の微粒炭の炭化 温度は約 $170^{\circ} \mathrm{C}$ となり, 反射率測定加求めた温度と は矛盾しない，岩波（1988）によると，林野火災や草地へ の火入れの最高温度は約 $400 \sim 800^{\circ} \mathrm{C}$ (ただし，シバ型草 地のみ $200 \sim 500^{\circ} \mathrm{C}$ ) とされており，分析に用いた微粒炭 は，林野火災や草地への火入れなどの植物燃焼で生成さ れたと考えられる.

Whitlock and Larsen (2001) によると, $100 \mu \mathrm{m}$ 以上 の微粒炭は，火災によって生成した後，沈積するまでに 遠くへは飛散しないとされている。 また，Ohlson and Tryterud (2000) は, スカンジナビアの北方針葉樹林の 燃焼実験を行い, $500 \mu \mathrm{m}$ 以上の微粒炭の多くは飛散せず に，近傍に沈積することを報告している，これより，彼 らは土壤中に $500 \mu \mathrm{m}$ 以上の微粒炭が含まれていた場合 には，現地で火災があった可能性が高いことを指摘して いる. 分析に用いた黒色土中には, $100 \mu \mathrm{m}$ 以上の微粒炭 が多量に含まれ，500 $\mathrm{m}$ 以上の微粒炭も含まれる（図 4)。また，花粉スライド法による微粒炭（お屯に $100 \mu \mathrm{m}$ 以下) の増減傾向之，篩い分け法による $100 \mu \mathrm{m}$ 以上拉 よび $500 \mu \mathrm{m}$ 以上の微粒炭の增減傾向は類似する．この ことは，黑色土中の微粒炭の粒径によって生成場所が相 違ないことを意味しており，これらの微粒炭が試料採取 地抢よび周辺で生成されたことを示唆している。また，

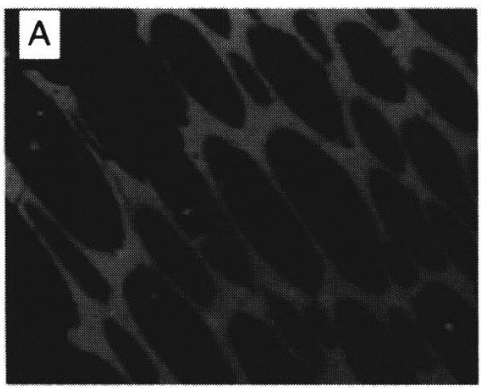

Black plant particle in Ando-soils

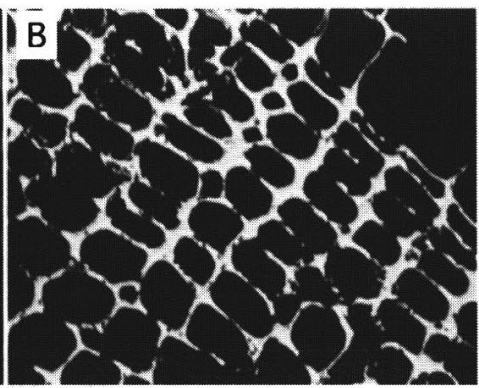

Charcoal produced after a forest fire

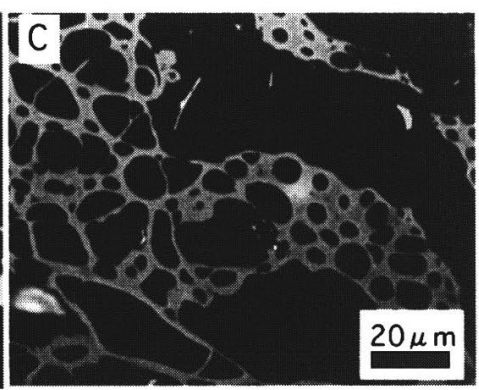

Charcoal produced after a grass fire

図 6 反射顕微鏡写真 (油浸 法)

A : 黒色上中に含まれた黒色植物片, B : 山火事跡 (香川県本島 2002 年 8 月) から採取した岑, C : 山焼き跡 （奈良県若草｜１２002 年 1 月）から採取した炭．均一に白く輝く特徵が類似する. 
今回の研究地域の黒色土は, 地形的に周囲よりも高位に 分布することから, 土壤や微粒炭が周辺から大きく移動 したとは考えにくい. 以上のことから, 研究地域の黒色 土に含まれる微粒炭の多くは，ほぼ現地性であると考え られ, 過去に試料採取地およびその近傍において林野火 災や草地への火入れなどの植物燃焼が起こったと推測さ れる。

2. 琵琶湖湖底堆積物中の微粒炭との関連性について 黒色土中には, 火山ガラスが多数含まれていた. 黒色 土に大まかな年代軸を入れるため，乾燥試料 $1 \mathrm{~g}$ あたり の火山ガラスの粒数を算出した (図 7). その結果, 深度 $20 \mathrm{~cm}$ と $70 \mathrm{~cm}$ 前後で火山ガラス粒数のピークか認めら

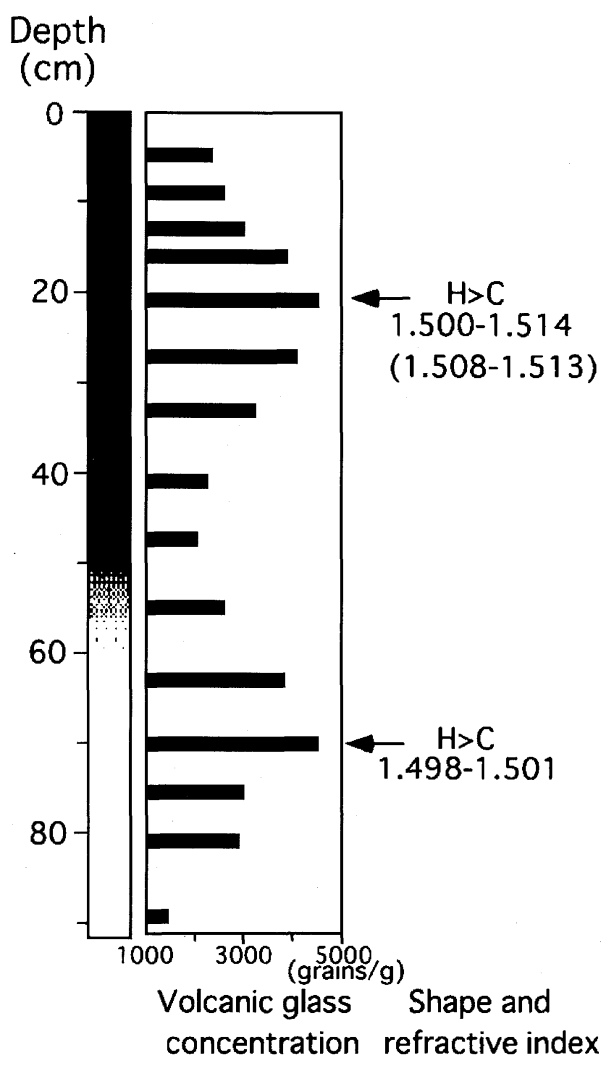

図 7 黒色土中に含まれる火山ガラスの粒数・形態・屈折率 火山ガラスの粒数は, $125 \mu \mathrm{m}$ 以上の砂粒子を実体顕微 鏡で観察し, 乾燥試料約 $0.2 \mathrm{~g}$ に含まれる火山ガラス 粒数を測定後, $1 \mathrm{~g}$ に換算した. 火山ガラスの形態は, 吉川 (1976) に基づき, $\mathrm{H}$ 型 (扁平型), $\mathrm{C}$ 型 (中間型), $\mathrm{T}$ 型 (多孔質型) の 3 種に分類した. $\mathrm{H}>\mathrm{C}$ は， $\mathrm{H}$ 型が 多く含まれ，C型が含まれることを意味する，屈折率 のカッコ内の値は, 集中度の高い範囲を示す.
れた．最屯多く含まれたこれらの試料中の火山ガラスの 屈折率測定・形態分類 (吉川, 1976) を行った (図 7). そ の結果，ガラスの形態は両者とも $\mathrm{H}$ 型が多く含まれ，C 型も含まれていた．また，屈折率は深度 $70 \mathrm{~cm}$ 前後では $1.498-1.501$, 深度 $20 \mathrm{~cm}$ 前後では $1.500-1.514$ で, 1.508-1.513 の範囲で集中度が高い. 黒色土が段丘上に 分布することを考慮して町田・新井 (2003) を参照する 之, 深度 $70 \mathrm{~cm}$ 前後は AT (姶良 $\mathrm{Tn}$ ) 火山灰起源のガラ ス, $20 \mathrm{~cm}$ 前後に含まれる火山ガラスは, 屈折率のレン ジが広いため, 複数の火山灰起源のガラスが混在してい ると考えられるが，K-Ah (鬼界アカホヤ) 火山灰起源の ガラスが多く含まれると考えられる. 次に，黒色土中の 微粒炭量と火山ガラス分析の結果を比較すると, 微粒炭 はAT 火山ガラス多産層位の前後ではほとんぞ含まれ ず, その約 $20 \mathrm{~cm}$ 上位から増加し, K-Ah 火山ガラス多 産層位付近で最む多くなる，このことは，AT 降灰以降 のある時期から，植物燃焼が起こったことを意味する.

一方, 琵琶湖湖底堆積物 (高島沖ボーリングコア)の 花粉スライド法 (お屯に $100 \mu \mathrm{m}$ 以下) による微粒炭量の 推移 (井上ほか, 2001) を見ると, 微粒炭量は AT 層準よ り上位の約 1 万数千年前頃から増加しはじめ, 1 万年前 以降急増し, K-Ah 層準の少し下位で最も含有量が多く なる. 琵琶湖湖底堆積物中の微粒炭量の変化と, 本研究 で扱った黒色土の微粒炭量の変化の傾向は類似する.こ のような琵琶湖西岸の黒色土と高島沖ボーリングコアに おける微粒炭量の変動傾向の類似性加ら, 黒色土分布域 で過去に植物燃燒が発生し，その際に微粒炭が飛散むし くは流出し，琵琶湖へ沈積したと考えられる．以上のこ とから, 琵琶湖湖底堆積物に含まれる微粒炭の発生地域 の1つとして琵琶湖周辺の黒色土分布域が考えられる.

\section{VI. まと め}

琵琶湖西岸に分布する黒色土中の黒色植物片につい て, 反射顕微鏡観察, 反射率測定, $\mathrm{H} / \mathrm{C}$ 比 (水素・炭素 比）分析，含有量分析などを行い，次のことを明らかに した.

1. 黒色植物片の反射顕微鏡観察, 反射率測定, $\mathrm{H} / \mathrm{C}$ 比分析から得られた特徵・分析值は, 現在の火災跡加ら 採取した炭や，炭化実験によって生成された炭と類似し ており,これらの黒色植物片は高温炭化によって生じた 微粒炭であると考えられる。

2. 反射率や $\mathrm{H} / \mathrm{C}$ 比から推測された黒色土中の微粒 炭の炭化温度加ら, 分析に用いた黒色土中の微粒炭は, 林野火災や火入れなどの植物燃焼によって生成したもの 
と考えられる.

3. 黒色土中には, $100 \mu \mathrm{m}$ 以上の微粒炭が多量に含 まれ，さらに $500 \mu \mathrm{m}$ 以上の微粒炭が含まれていた．現 在の森林火災実験との比較加ら, 過去に試料採取地や近 傍で植物燃焼が起こっていた可能性が高いと考えられ た.

4. 黒色土の微粒炭は, AT 火山ガラスの多産層位よ りも上位で多く含まれはじめ，上位に向かって含有量は 増加し, $\mathrm{K}-\mathrm{Ah}$ 火山ガラスの多産層位前後で最屯多く含 まれていた.このような傾向は, 琵琶湖湖底堆積物の微 粒炭量の変化亡類似する．黑色土分布域で起こった植物 燃焼により発生した微粒炭が，琵琶湖へ流入したと類推 された.

謝辞 森林総合研究所関西支所の金子真司氏には，試 料採取の際に大変お世話になり, また土色のデー夕など を提供していただいた， H/C 比測定にあたっては，島根 大学総合理工学部の沢田順弘教授, 三瓶良和助教授に, 反射率測定にあたっては, 山口大学教育学部の千々和一 豊助教授に，ご指導いただいた．京都府立大学大学院農 学研究科の高原 光教授には, 研究を進める上で便宜を 図っていただいた，大阪市立大学大学院理学研究科の熊 井久雄名誉教授, 三田村宗樹助教授，奥平敬元講師には 有益なご助言をいただいた，京都府立大学大学院農学研 究科森林環境学研究室, 大阪市立大学人類紀自然学教室 の方々には大变お世話になった，また，查読者である森 林総合研究所四国支所の鳥居厚志氏の指摘によって, 本 稿は大きく改善された. なお，本研究の遂行にあたって は, 平成 14,15 年度科学研究費補助金 (日本学術振興会 特別研究員奨励費, 代表者: 井上 淳), 平成 16 18 年 度科学研究費補助金基礎研究 B2（課題番号 : 16340157, 代表者: 吉川周作）の援助を受けた。 以上の方々に心か らのお礼を申し上げます。

\section{引 用 文 献}

千々和一豊・西村祐二郎・木場基之（1998）顕微測光シ

ステム Leitz MPV combiによる反射率の測定. 山口 地学会誌, 40, 9-16.

土じょう部（1976）林野土壌の分類 (1975). 28 p, 林業 試験場研究報告, 280 .

細野 衛・佐瀬 隆 (1997) 黒ボク土生成試論. 第四紀, 29, $1-9$.

井上 淳・高原 光・千々和一豊・吉川周作 (2005) 滋 賀県曽根沼堆積物の微粒炭分析による約 17,000 年以
降の火事の歷史. 植生史研究， 13，47-54.

井上 淳 - 高原 光・吉川周作 ・ 井内美郎 (2001) 琵琶 湖湖底堆積物の微粒炭分析による過去約 13 万年間の 植物燃焼史. 第四紀研究，40，97-104.

Inoue, J. and Yoshikawa, S. (2003) Identification of charcoal in Quaternary sediments and estimation of the charred temperature by reflectance measurements and $\mathrm{H} / \mathrm{C}$ ratio analysis and observation through reflectance and scanning electron microscopy. Journal of Geoscience, Osaka City University, 46, 127-134.

岩波悠紀（1988）火入れによる攪乱. 矢野悟道編「日本 の植生一侵略と攪乱の生態学一 出版会.

Jones, T.P., Scott, A.C. and Cope, M. (1991) Reflectance measurements and the temperature of formation of modern charcoals and their implications for studies of fusain. Bulletin of the Geological Society of France, 162, 193-200.

MacDonald, G.M., Larsen, C.P.S., Szeicz, J.M. and Moser, K.A. (1991) The reconstruction of boreal forest fire history from lake sediments, a comparison of charcoal, pollen, sedimentological and geochemical indices. Quaternary Science Reviews, 10, 53-71. 町田 洋・新井房夫（2003）新編火山灰アトラス〔日本 列島とその周辺]. $336 \mathrm{p}$, 東京大学出版会.

日本の地質「近畿地方」編集委員会（1987）日本の地質 6 近畿地方. $297 \mathrm{p}$, 共立出版.

Ogden III, J.G. (1986) An alternative to exotic spore or pollen addition in quantitative microfossil studies. Canadian Journal of Earth Science, 23, 102-106.

小椋純一・山本進一・池田晃子 (2002) 微粒炭分析汃ら 見た阿蘇外輪山の草原の起源. 名古屋大学加速器質量 分析計業績報告書, $13,236-240$.

Ohlson, M. and Tryterud, E. (2000) Interpretation of the charcoal record in forest soils : forest fires and their production and deposition of macroscopic charcoal. The Holocene, 10, 519-525.

阪口 豊 (1987) 黒ボク土文化. 科学, 57, 352-361.

Sawada, Y., Sampei, Y., Hyodo, M., Yagami, T. and Fukue, M. (2000) Estimation of emplacement temperatures of pyroclastic flows using $\mathrm{H} / \mathrm{C}$ ratios of carbonized wood. Journal of Volcanology and Geothermal Research, 104, 1-20. 
Scott, A.C. (2000) The Pre-Quaternary history of fire. Palaeogeography, Palaeoclimatology, Palaeoecology, 164, 281-329.

Swain, A.M. (1973) A history of fire and vegetation in northeastern Minnesota as recorded in lake sediments. Quaternary Research, 3, 383-396.

高原 光 (1995) 画像解析による炭素片分析法一Macintosh 用画像処理用ソフト NIH Image を用いて. 日本 第四紀学会講演要旨集, 25, 52-53.

鳥居厚志 - 金子真司・荒木 誠（1998）近畿地方の 3 地 点の黒色土の生成，とくに母材と過去の植生につい
て. 第四紀研究，37，13-24.

Whitlock, C. and Larsen, C. (2001) Charcoal as a fire proxy. Smol, J.P., Birks, H.J.B. and Last, W.M. (eds.) Tracking environmental change using lake sediments Vol. 3, Terrestrial, algal, and Siliceous Indicators : 75-97, Kluwer Academic Publisher.

山野井 徹 (1996) 黒ボクの成因に関する地質学的検討. 地質学雑誌, 102，526-544.

吉川周作（1976）大阪層群の火山灰層について．地質学 杂隹誌，82，497-515.

\title{
Research on Black Plant Particles in Ando-soils Distributed around Lake Biwa, Central Japan, with a New Avenue of Research on Charcoal Particles in Ando-soils
}

\author{
Jun Inoue* and Shusaku Yoshikawa*
}

Ando-soils are distributed widely in Japan. Previous studies showed black plant particles included in Ando-soils that are considered as charcoal particles. Our studies confirmed that black plant particles in Ando-soils distributed around Lake Biwa are charcoal particles by observation of reflectance microscopy, reflectance measurements, and $\mathrm{H} / \mathrm{C}$ ratio analysis. These black plant particles shine white under reflectance microscopy, and have higher reflectance and lower $\mathrm{H} / \mathrm{C}$ ratios similar to modern charcoal. These results prove that charcoal particles are included in Ando-soils in this area. The values of reflectance and $\mathrm{H} / \mathrm{C}$ ratio suggest that charcoal particles were probably the result of forest fires or grass fires. The charcoal concentration increases from upper AT Volcanic glass-rich stratum to $\mathrm{K}$-Ah Volcanic glassrich stratum. This tendency is almost consistent with that of charcoal concentrations in Lake Biwa sediments. Therefore, some charcoal particles in Lake Biwa sediments are probably derived from fires in Ando-soils distributed in areas around Lake Biwa.

\footnotetext{
* Department of Biology and Geoscience, Graduate School of Science, Osaka City University. 3-3-138 Sugimoto, Sumiyoshi-ku, Osaka, 558-8585, Japan.
} 